Jan Mrázek, Wayang \& Its Doubles:Javanese Puppet Theatre, Television, and the Internet. Singapore: National University of Singapore Press, 2019, xiv + 349 pp. ISBN: 9789814722957, price: 49.00 SGD (paperback).

For over two centuries the Javanese puppet theatre, wayang kulit, has fascinated scholars the world over. So much has been written and said about the various forms of wayang that one wonders what else there is to add to this immense body of knowledge. Jan Mrázek found a new topic and a unique conceptualization for his newest book in which he explores "the marriage of wayang and television" (p. 10). The "marriage" is a metaphor referring to the complex, sometimes paradoxical relationship between wayang and television which threads through the book. The closeness of the two mediums suggests the possibility of a perfect marriage but actually it is one "full of conflict" due to unbridgeable differences. Television claims to show "authentic" wayang but what is shown in reality is a representation, a reimagining, an imitation of wayang, or a "double". Even though wayang and television may seem very much alike, they are simultaneously very much unalike. The heydays of Indonesiar (roughly 1995-2005), the first major television company that started to regularly broadcast wayang on national television, are the main prism of the book through which Mrázek explores the epistemological relationship between television and wayang.

The love-hate relationship is discussed on the basis of a great number of interviews with people working in the wayang world, such as dalang (master puppeteers), sponsors, spectators, composers, and academics, but also in the television industry like producers and owners of national and local television companies that broadcast wayang. To this, the author adds his own experience of watching wayang. The multiplicity of these voices and experiences are set in conversation between a string of philosophers: Karl Marx, Martin Heidegger, Maurice Merleau-Ponty, Jacques Derrida, Samuel Weber, and James Siegel. These philosophers guide and shape the epistemological reflections on wayang and television while acknowledging that each of the voices presented in the book stem from different ways of being and therefore from different worldviews. The conversations that emerge from this are framed in an imagined coffee shop setting, much in the manner of Mrázek's introduction to his earlier work Puppet Theatre in Contemporary Indonesia (2002). Wayang \& Its Doubles is set up as if we are sitting in a coffee shop listening to the various perspectives about this metaphorical marriage between television and wayang.

This approach affords epistemological reflections drenched in wit that guide us on a journey of thought about how wayang and televised imaginings and phantasies of wayang are part and parcel of the world we live in today. In

BIJDRAGEN TOT DE TAAL-, LAND- EN VOLKENKUNDE

(C) SADIAH BOONSTRA, 2021 | DOI:10.1163/22134379-17701010

This is an open access article distributed under the terms of the CG,BY-NC 4.olicense 
Chapter 1 we gain an understanding of how wayang and television have increasingly come to resemble each other. Wayang has developed to become more suitable for television, and television has become more like wayang, adjusting ways of filming appropriate for broadcasting wayang. The relationship between the two was predestined, as wayang has always flirted with other televisionrelated technologies—such as electricity, radio, light, sound — and media like radio, audio- and video-recording. Mrázek subsequently looks at the pull and push factors between television and wayang. The characteristics of television and wayang seem to be a perfect match, yet in practice both worlds seem hard to unite. What is deemed "authentic" and "characteristic" of wayang does not necessarily come across in televised versions of wayang. Moreover, the interests and knowledge of both worlds are too far apart to establish a successful marriage. What works in real life performances might not work at all on television. The third chapter explores how space, time, and movement influence the experience of watching wayang. Attending and watching wayang in real life is a completely different experience than watching on television in the comfort of your home. Watching wayang is something one does not exclusively do through watching and listening, but it is first and foremost a bodily sensation. Being present at a wayang show touches on all bodily senses from embarking on the journey to the performance place, smelling food vendors, watching other spectators, the musicians and singers, eating and drinking, napping, and sensing the change of atmosphere and time as the night goes on. How the audience chooses between watching wayang at home with just a click on the remote control, or attending a wayang show in real life depends on a negotiation of how the spectator chooses for the body to relate to space, time, and movement. Acknowledging that the relationship between wayang and television is complicated, chapter four discusses a number of alternative attempts between 1997 and 2005 that try to move away from the Indonesiar model to build another, better relationship between television and wayang. These initiatives reconfirm that marrying television and wayang remains a challenge. The last chapter looks at local, private television stations, as well as wayang and the internet. Local television stations might be more embedded in the world of wayang, which makes collaborations easier and smoother. The newest experiences of watching wayang on online platforms that enable the livestreaming of shows is a dream come true that was unattainable for televised wayang. Watching wayang online is similar yet dissimilar to watching wayang on television. Livestreaming comes with the ability to chat with other spectators in live chatrooms, which mitigates some of the elements one misses when watching wayang on television. It provides space to chat and joke with other spectators. Yet old problems continue to exist, as we have to acknowledge that television 
and the internet are wayang's imitations or doubles: they are not wayang, but imagined representations of itself that never fully represent wayang.

Reflecting on the issue of representation Mrázek writes "like and unlike television producers, [scholars] represent wayang — record it, frame it, zoom in on details that they deem interesting and managing its image and, in the process their own" (p. 9). While philosophical contemplations are nuanced, recontextualized, and situated in Javanese localities, the frames of knowledge and thinkers in the book originate from Europe and America-all of whom are men, in a similar manner that wayang is still very much a man's world. Since the start of wayang scholarship, such modernist frames of European and American male thinkers have been used to gain an understanding of wayang. These frames of representation are closely connected to the specific historical situation that television grew out of, which the author recognizes and acknowledges. It is a particular worldview tied to the notion of "modernity", which stands for "modern-global culture" (Chapter 1), a view shared by many interviewees throughout the book. Modernist frames though run the danger of obscuring decolonial and intersectional perspectives of wayang. A decolonial approach would mean an attempt to detach from structures of modernity and coloniality - two sides of the same coin — to (re)establish old and new ways of thinking, languages, ways of life and being in the world which rhetorics of modernity do not allow for. Wayang \& Its Doubles is without a doubt a brilliant book and this review can only suggest the depth and richness of Mrázek's study. It is a wonderful and witty read, a valuable addition to the body of scholarly knowledge of wayang, and a must-read for anyone interested in wayang. At the same time it makes one wonder when decolonial, intersectional frames of representation will arrive for wayang.

\section{Sadiah Boonstra}

Melbourne University, Melbourne, VIC, Australia

sadiah.boonstra@unimelb.edu.au 